\title{
SIMILARITIES AND DIFFERENCES IN THE LANGUAGE OF OFFICIAL RECORDS IN SELECTED CRIMEAN AND OTTOMAN JUDICIAL BOOKS*
}

\author{
KATARZYNA STEFANIAK-RAK \\ Department of Asian Studies, Section of Turkic, Mongolian and Korean Studies \\ Adam Mickiewicz University \\ al. Niepodległości 24, 61-714 Poznań, Poland \\ e-mail: kasiast@amu.edu.pl
}

The aim of this paper is to discuss both similarities and differences in selected judicial books. Legal terminology and functional vocabulary will be analysed on the basis of words from a Crimean judicial book. Subsequently, books from different regions of the Ottoman Empire will be analysed with regard to their presence. Judicial books are registries which were written in Ottoman Turkish in judicial offices. This publication is an attempt at answering the following questions: Were the words and formulae used in the records similar? Are the names of objects the same? Was the language of the local population reflected in the court records?

Key words: judicial books, Crimea, Ottoman Empire, legal terminology, Crimean-Tatar language, Ottoman language.

\section{Introduction}

The language of Ottoman judicial books called sicills and defters is very distinctive. It differs significantly from the literary language. It results, first and foremost, from the contents of the books. Grzegorzewski (1912, p. 7) characterises court records as "judicial books or written records to which the judge himself, i.e. kadi or his deputy or a writer under the supervision of the kadi who is the supervisor of these books (sicill idaresi), adds all acts of public and private life which are subject to notarial and judicial review." Fekete (1926, p. 58) defines defters in the following way: "a list, a record of notes ranging from the official ones to the private ones. (...) Defters

* This paper was written with the financial support of the National Science Centre (Poland), grant no. 3810/B/H03/2011/40. 
include merely formal (formulaic) parts such as an introduction, ending and a title which were abbreviated correctly" (my translation, K. S.-R.).

\section{Legal Terminology in Judicial Books}

The judicial books were written in Ottoman Turkish. It was also the official language of judicial offices in the Ottoman Empire and the Crimea, characterised by formulae, a special terminology and professional vocabulary, which were not used outside the court, chambers of the kadi, or seats of authorities for the most part. They were used by the educated and enlightened. Next to them, there are colloquial expressions from daily life which are found on the occasion of making the inventory of a deceased person's estate.

Sicills are an exceptionally valuable source of knowledge about the language as well as the everyday life of the inhabitants of the region where a given book was created. The contents of several books (Aș-Ṣuqūq aš-šari'‘̄yya wa as-siğillāt almar 'iyya vol. 10; İstanbul Mahkemesi 121 Numaralı Şer ’iyye Sicili; İstanbul Kadı Sicilleri Üsküdar Mahkemesi 1 Numaralı Sicil; Şer'iye sicilleri vols I-II; Das sicill aus Skopje. Kritische Edition und Kommentierung des einzigen vollständig erhaltenen Kadiamstsregisterbandes (sicill) aus Üsküb (Skopje); Osmanlı Vesikaların Okumaya Giriş) have been analysed in order to find out whether the terminology and the vocabulary of the notes from the Crimea are common for the judicial offices regardless of the place where they were taken down. Because of the enormous variety of the contents of the sicills, only some of the most frequently attested expressions and words in the $10 \mathrm{th}^{1}$ book were chosen, and subsequently the contents of the other records were analysed. Thanks to that, it will be easier to check if the terms and expressions were fixed (identical or similar in the Ottoman Empire and the vassal states), or if they are characteristic of the records from the 17 th-century Crimea.

\subsection{Words and Terms ${ }^{2}$}

'āciz, 'āciz olmak 'unable, incapable' (SŠSM10, p. 141), (IM121, p. 33), (IKS, p. 412), (ŞS, p. 221); ahz 'receiving; exaction' (SŠSM10, p. 137), (IM121, p. 26), (DSS, p. 299), (ŞS, p. 25), (OVO, p. 190); așāleten 'in one's own name; in propria persona' (SŠSM10, p. 78), (IM121, p. 49), (DSS, p. 723), (ŞS, p. 328); ba'de 'then, after' (SŠSM10, p. 77), (IKS, p. 125), (IM121, p. 6), (DSS, p. 300), (OVO, p. 190), (ŞS, p.

\footnotetext{
${ }^{1}$ The language of other judicial books from the Crimea is similar. The proceedings of the hearings from these sicills contain the same terms and words, therefore similarities and differences in the language of official documents will be provided on the basis of SŠSM volume 10 written in the years 1077/1666-1080/1669-1670. In several places there appear examples from volumes 13 (1078/1668-1079/1669) and/or 15 (1085/1674-1086/1675).

${ }^{2}$ The meaning of the words has been provided on the basis of the Redhouse Dictionary (Redhouse 2000).
} 
328); bey ' 'sale' (SŠSM10, p. 138), (IM121, p. 9), (ŞS, p. 328); beyān, beyān etme 'declaration' (SŠSM10, p. 18), (IM121, p. 5), (DSS, p. 722), (IKS, p. 110); beyyine 'proof, argument' (SŠSM10, p. 40), (IKS, p. 116); bi'l-muvācehe 'in confrontation; by confronting' (SSSM10, p. 105), (IKS, p. 114); bi 't-țaleb 'on request, according to the will' (SŠSM10, p. 138), (IM121, p. 51), (DSS, p. 723), (OVO, p. 190), (ŞS, p. 328); bi-t-tamām 'completely, fully' (SŠSM10, p. 81), (IKS, p. 103), (ŞS, p. 325); bit-țav 'voluntarily' (SŠSM10, p. 80), (IKS, p. 218); deyn 'debt, obligation; obligatory act' (SŠSM10, p. 80), (IKS, p. 125), (DSS, p. 640); edā, edā ètme (eyleme) '1. affectation. 2. payment, paying a debt' (SŠSM10, p. 23), (DSS, p. 180), (ŞS, p. 267), (OVO, p. 190), (IKS, p. 125), (IM121, p. 23); ferāgat 'abnegation; abandonment, resignation' (SŠSM10, p. 78), (IM121, p. 33); fevt olmak 'to die' (SŠSM10, p. 127), (IKS, p. 116), (IM121, p. 3), (DSS, p. 266), (OVO, p. 190); firār eyleme 'escape; desertion' (SŠSM10, p. 131), (ŞS, p. 25); hayyiz-i kabūl 'acceptance by a party' (SŠSM10, p. 23), (IKS, p. 112), (ŞS, p. 328); hudüd 'border; limit' (SSSSM10, p. 138), (IKS, p. 221), (IM121, p. 4), (DSS, p. 722), (ŞS, p. 294); huș̣̄̄ṣ 'issue, subject, case' (SŠSM10, p. 23), (IM121, p. 6), (DSS, p. 251), (ŞS, p. 325), (OVO, p. 189); $\imath k b \bar{a} z$, $\imath k b \bar{a} z$ etme 'holding, withholding' (Devellioğlu 2006, p. 454), (SŠSM10, p. 138), (IKS, p. 216); ibrā 'an acquitting, absolving' (SŠSM10, p. 127), (IKS, p. 220), (IM121, p. 6); ibrā-i ısḳāt; ibrā ve ibtidā 'start, beginning' (SŠSM10, p. 98), (IKS, p. 413); icāre 'rent' (SŠSM10, p. 89), (IKS, p. 103); ikrār, iḳrār etme 'confession; declaration' (SŠSM10, p. 23), (IM121, p. 6), (DSS, p. 722), (ŞS, p. 25), (IKS, p. 103); $i k r a \bar{r}$ ve i 'tirāf, iḳāar ve i 'tirāf etme 'confession and admission' (SŠSM10, p. 16), (DSS, p. 723), (ŞS, p. 266); inkār , inkār etme '1. a denying; an ignoring. 2. contest' (SŠSM10, p. 40), (IM121, p. 6), (IKS, p. 200), (ŞS, p. 325), (OVO, p. 190); is bāt etme 'proving; demonstration; confirmation' (SŠSM10, p. 137), (IKS, p. 112), (ŞS, p. 291); iskāt eyleme 'throwing down; rejection, dismissing' (SŠSM10, p. 76), (IM121, p. 51), (ŞS 292); iştirā 'purchase, buy' (SŠSM10, p. 18), (IM121, p. 27), (ŞS, p. 328); kabūl ètme/eyleme 'acceptance, admission, acceptation' (SŠSM10, p. 75), (IKS, p. 109), (IM121, p. 6), (DSS, p. 478), (ŞS, p. 25), (OVO, p. 190); kabż, kabż eyleme 'acquisition, seizing, a taking into possession' (SŠSM10, p. 125), (IKS, p. 115), (IM121, p. 26), (DSS, p. 516), (ŞS, p. 325), (OVO, p. 190); karż 'loan, debt' (SŠSM10, p. 72), (IKS, p. 115); kefil, kefil olma 'guarantor, surety; standing surety' (SŠSM10, p. 89), (OVO, p. 190), (IKS, p. 102), (ŞS, p. 328); keyfe-mā-yeşā ve yahtār 'in accordance with the will and wish' (SŠSM10, p. 78), (ŞS, p. 23); kıt 'a 'piece, part' (SŠSM10, p. 50), (IM121, p. 4); kirā 'rent; tenacy' (SŠSM10, p. 48), (IKS, p. 116), (IM121, p. 9), (DSS, p. 510); maktūl 'murdered, killed' (SŠSM10, p. 59), (IKS, p. 113); ma 'lūm 'familiar, known' (SŠSM10, p. 127), (IM121, p. 4), (DSS, p. 300), (ŞS, p. 42); mațlūb 'wished for, desired' (SŠSM10, p. 18), (IM121, p. 9), (DSS, p. 449), (OVO, p. 190); meblag 'sum (of money), amount' (SŠSM10, p. 40), (IKS, p. 205), (IM121, p. 39), (DSS, p. 266), (ŞS, p. 25); meclis-i şer' 'Islamic court' (SŠSM10, p. 23), (IKS, p. 112), (IM121, p. 5), (DSS, p. 299), (ŞS, p. 312); mecrūh '1. wounded, injured. 2. rejected' (SŠSM10, p. 49), (IKS, p. 112); merḥūm 'deceased' (SŠSM10, p. 125), (IKS, p. 109), (IM121, p. 4), (ŞS, p. 324); merkūm 'mentioned, noted' (SŠSM10, p. 137), (IM121, p. 6), (DSS, p. 299), (ŞS, p. 325), (OVO, p. 189); mesfür 
'mentioned, noted' (SŠSM10, p. 23), (IKS, p. 223); metrūkāt 'inheritance; effects of the deceased person' (SŠSM10, p. 23), (IKS, p. 125); mezbür 'mentioned, noted' (SŠSM10, p. 127), (IKS, p. 412), (IM121, p. 5), (DSS, p. 219), (ŞS, p. 25), (OVO, p. 190); mezkūur 'mentioned, noted' (SŠSM10, p. 18), (IKS, p. 103), (DSS, p. 201), (ŞS, p. 25); minvāl-i meşrūh 'in the explanations, by means of explanation' (SŠSM10, p. 18), (IM121, p. 103); minvāl-i muharrer 'in writing' (SŠSM10, p. 14), (IM121, p. 23), (ŞS, p. 25); mūcib '1. necessary, indispensable. 2. reason, cause' (SŠSM10, p. 23), (IM121, p. 3), (DSS, p. 197); muhallefāt 'inheritance' (SŠSM10, p. 18), (IKS, p. 218), (ŞS, p. 325); mūmā ileyh 'aforementioned, named' (SŠSM10, p. 18), (IM121, p. 3), (DSS, p. 201); muvācehe 'confrontation' (SŠSM10, p. 138), (IM121, p. 6), (ŞS, p. 25); muvāfik 'appropriate, agreeable, suitable' (SŠSM10, p. 137), (IKS, p. 200), (DSS, p. 180), (ŞS, p. 290); müdde 'î 'plaintiff; accuser' (SŠSM10, p. 18), (IKS, p. 210); müsbet 'proved, established' (SŠSM10, p. 18), (DSS, p. 510); müşārün-ileyh 'named, aforementioned (used for high officials and celebrities)' (SŠSM10, p. 16), in (DSS, p. 299) it is müssar ileyh, (IKS, p. 413); müteveffā 'deceased, dead' (SŠSM10, p. 9), (IKS, p. 109), (IM121, p. 9), (DSS, p. 266), (ŞS, p. 298); nafaka 'maintenance, alimony' (SSSSM10, p. 4), (IKS, p. 111), (ȘS, p. 230); nașb, nașb olma 'appointment, nomination; being designated, appointed to a position' (SŠSM10, p. 17), (OVO, p. 189), (IKS, p. 101), (ŞS, p. 48); nizā' 'dispute, quarrel' (SŠSM10, p. 101), (DSS, p. 723), (ŞS, p. 288); șābit 'authenticated, agreed, proved' (SŠSM10, p. 16), (IM121, p. 57), (DSS, p. 722), (ŞS, p. 324), (IKS, p. 114); su'äl 'question' (SŠSM10, p. 18), (OVO, p. 190), (SSS, p. 291); șulh, șulh etme 'reconciliation, settlement; making peace' (SŠSM10, p. 82), (IKS, p. 112); süüut 'being proved, certain' (SŠSM10, p. 80), (IKS, p. 125), (IM121, p. 6), (DSS, p. 300); şāhid 'a witness' (SŠSM10, p. 23), (IKS, p. 112); şehādet-i şer'iyye 'testimony in accordance with Sharia' (SŠSM10, p. 23), (IKS, p. 102), (ŞS, p. 267); şirā 'purchase, buy' (SŠSM10, p. 40), (IM121, p. 26); tahrīr 'record, writing; registration' (SŠSM10, p. 79), (DSS, p. 303), (OVO, p. 189); takdìr, takdìr olma 'appreciation; estimate, being estimated' (SŠSM10, p. 73), (IKS, p. 102), (IM121, p. 6), (ŞS, p. 291); takrīr-i kelām 'giving utterance to words, speaking' (SŠSM10, p. 138), (ŞS, p. 25), (IM121, p. 51), (DSS, p. 722); taleb, țaleb etme 'request; wishing, longing for; requesting, asking for' (SŠSM10, p. 137), (IKS, p. 113), (SSS, p. 25), (OVO, p. 190), (DSS, p. 297); tașarruf 'possession, disposal; saving (money)' (SSSSM10, p. 18), (IM121, p. 67), (IKS, p. 109), (ŞS, p. 328); tașdīk, tașdik etme 'confirmation, assertion; an affirmation' (SŠSM10, p. 138), (IM121, p. 6), (DSS, p. 723), (ŞS, p. 23), (IKS, p. 113); ta'yin 'appointing, designating; appointment' (SSSSM10, p. 118), (IKS, p. 110), (DSS, p. 299), (SSS, p. 230), (OVO, p. 189); teslìm 'delivery; submitting' (SŠSM10, p. 35), (DSS, p. 303), (IM121, p. 24), (IKS, p. 111), (DSS, p. 516); vași 'guardian, executor' (SSSSM10, p. 38), (IKS, p. 152), (IM121, p. 95), (ŞS, p. 298); vech-i meşrūh (üzere) 'in the manner described' (SŠSM10, p. 53), (IM121, p. 26), (DSS, p. 303); vekālet 'proxy' (SŠSM10, p. 125), (IKS, p. 125), (ŞS, p. 291); vekīl 'proxy, attorney' (SŠSM10, p. 137), (IKS, p. 113), (ŞS, p. 289); verāset 'inheritance, heritage' (SŠSM10, p. 43), (IM121, p. 9), (DSS, p. 266); żarar 'damage, injury' (SŠSM10, p. 140), (IKS, p. 210); zikr 'a mentioning, mention' (IM121, p. 5), (DSS, p. 197), (ŞS, p. 25), (IKS, p. 102); zimmet 'charge; 
debt' (SŠSM10, p. 3), (IKS, p. 109), (IM121, p. 39), (DSS, p. 669), (ŞS, p. 278), (OVO, p. 190); żimmī 'non-Muslim (mainly Christian)' (SŠSM10, p. 139), (IKS, p. 113), (IM121, p. 22), (DSS, p. 268), (ŞS, p. 292); ziyāde 'more; much; very' (SŠSM10, p. 124), (IKS, p. 103), (IM121, p. 33).

The above examples taken from the pages of the 10th judicial book from the Crimea can also be found on the pages of the majority of the analysed records from other sicills. An analysis of the issue was first carried out as part of my doctoral dissertation entitled "Protokoły rozpraw sądowych XVII wiecznego Krymu. Analiza językowa i kulturowa" [The proceedings of the hearings from 17th-century Crimea. A linguistic and cultural analysis] (Stefaniak-Rak 2011). The terms and legal formulae as well as selected colloquial vocabulary also appear in the analysed books from different chambers in the Ottoman Empire, which proves that they were fixed and constant.

In general, the recording clerks did not allow for arbitrariness and individual formulation of the records, but used standard phrases and terms. According to Ergene (2003, p. 134): "there are indications in the court records that what is reported in the sicills as the speech of the litigants is in fact the translation of their voices into the official language of the legal system". Then he gives an example of a case in which some Christian woman was involved: "Alternatively, the officials of the court may have reconstructed her speech while it was being recorded in the court records. In any case, what we observe in this example is a translation of her actual thoughts, feelings, and perhaps even words into a legal statement that was acceptable according to the existing legal and religious norms." It leads to the conclusion that in some cases witnesses' statements could influence the court records and explains why some colloquial words and grammatical forms appear in the judicial books from the Crimea.

Apparently, each of the analysed books has a different style. Each style has its distinctive features, which is due to various factors. The most important of the factors are:

(i) Types of the documents written down in the volume (hüccet 'certificate, right of ownership, evidence', ferman 'decree, edict', ilam 'sentence', arzuhal 'application, petition', etc.). These documents, for example fermans, were written in the official language which is very difficult to understand compared to the Crimean yarliks. One of the most important sources devoted to edicts and documents from the Crimea (also these excerpted from the defters) is the collection published by Véliaminov-Zernof in 1864. Mary Ivanics describes this book in her article: "Among the numerous editions the most significant work is that of Veljaminov-Zernov who published 378 letters in Arab transliteration from the documents of the Ministry of Foreign Affairs in Moscow. He initiated the publication of the defters too" (Ivanics 1975, p. 6) ${ }^{3}$.

The use of any colloquial expressions or simplifications in the official documents was rather unacceptable. They were organised according to special rules and order. Ordinary documents (of various types and contents) were

\footnotetext{
${ }^{3}$ The different yarliks, documents and letters from Crimea were published (inter alia) by Kurtoğlu (1937), Kurat (1940), Vásáry (1982), Święcicka (2002) and many other authors.
} 
characterised by the formulaic language. However, upon reading them, it can be easily noticed that some recording clerks had the tendency to simplify their language and style. They used all expressions indispensable for writing an official record; nonetheless, frequently enough some simplification of the language of the notes can be observed. One can get the impression that they were under the visible influence of the language of the people who gave statements or testimonies and most certainly used the colloquial language.

ii) The place a given book comes from, the vocabulary used by the clerks to describe events and situations in which individuals who came to court found themselves. This phenomenon applied to the parts of the notes which refer to testimonies and in which circumstances of a given event are established. Then the influence of the local language on the style of the documents noted by the kadi is visible.

The above factors did not affect the legal terminology of the time. In the majority of the analysed books, one can find the same terms, such as vași 'guardian, custodian', bey' 'sale', kabż 'acquisition', or kefil 'guarantor'. Some of them are fixed and always appear when the need arises, others sometimes have several synonyms which are used interchangeably, e.g. deyn, karż, zimmet occurring in the meaning of 'debt'. Words and formulae characteristic of the language of the law and the chambers are fixed and invariable, which is clearly exemplified by the terms chosen for the purpose of this comparison. Regardless of the region (i.e. the Crimean Khanate or the Ottoman Empire), the professional vocabulary in the sicills is universal. Whilst reading the contents of the mentioned books, it may be observed that the recording clerks used some selected expressions and formulae much more frequently than others. Some of them had several synonyms, which is evident in the above list, e.g. merkuum, mesfür, $m e z b \bar{u} r, m e z k \bar{u} r$ 'mentioned, noted'. These expressions were used interchangeably depending on the clerk's preferences. In the 10th judicial book from the Crimea, mezbu $r$ and mezkūr are the most prevalent. The richness of the legal language was essential for the proper functioning of the chamber and the court. It facilitated formulating notes which were written according to a specific and strictly defined order, with the use of specific terms and phrases.

\section{Functional Vocabulary and Material Culture in Judicial Books}

When reading the official records, one needs to pay attention to the colloquial vocabulary which occurs mainly in the estate inventory of the deceased in the judicial books and serves as a representation of the material and non-material culture of the inhabitants of different regions. Nadine Frantz (1998, p. 791) writes: "The term material culture has come to be used by several disciplines to designate the physical, material objects that cultures create and use in the course of common life. Contained within this designation are objects such as chairs, tools, and other artifacts of daily life as well as those that have traditionally been held as evidence of 'high' culture such as music, visual and plastic arts (...)". Sometimes colloquial words can be found 
in compact notes when it is a part of the witnesses' testimonies in the recorded case. The list below was created to establish whether the recording clerks in different registers from the Crimean Khanate and the Ottoman Empire used the same names of objects, comestibles, and clothes.

arpa 'barley' (SŠSM10, p. 111), (ŞS, p. 338); ațlās 'satin' (SŠSM10, p. 92), (DSS, p. 355); bog ça/bohça 'bundle' (SŠSM10, p. 107), (IKS, p. 105), (DSS, p. 269); bugday 'wheat' (SŠSM10, p. 105), (IKS, p. 435), (DSS, p. 311), (ŞS 335); buza 'calf' (SŠSM10, p. 96), (DSS, p. 311); çakşır/çahşıı 'trousers secured round the waist in folds, and sewn to light leather boots at the ankles (Redhouse 2000, p. 237)' (SŠSM10, p. 92), (IKS, p. 104); çavdar 'rye' (SŠSM10, p. 41), (DSS 311); çokal çuka/çuha 'broadcloth' (SŠSM10, p. 30), (IKS, p. 104), (DSS, p. 267), (ŞS, p. 335); çuvāl 'sack' (SŠSM10, p. 92), (IKS 108), (ŞS 340); tarl/darl 'millet' (SŠSM10, p. 119), (IKS, p. 108); don [archaic] 'clothing, garment', (also) 'pair of drawers, underpants' (Redhouse 2000, p. 309), (SŠSM10, p. 93), (IKS, p. 104); döşsek 'mattress' (SŠSM10, p. 85), (IKS, p. 258), (DSS, p. 270), (ŞS, p. 338); duhān 'tobacco' (SŠSM10, p. 47), (DSS, p. 294); eger (eyer) 'saddle' (SŠSM10, p. 47), (DSS, p. 668); entari 'dress, loose robe' (SŠSM10, p. 30), (DSS, p. 355); fuçī/fıçı 'barrel' (SŠSM10, p. 91), (IKS, p. 264); fincān '(tea/coffee) cap' (SŠSM10, p. 92), (DSS, p. 267); gömlek 'shirt' (SŠSM10, p. 138), (IKS, p. 104), (DSS, p. 267), (ŞS, p. 338); hegbe 'saddle-bag' (SŠSM10, p. 112), (IKS, p. 105); hurdevāt 'scraps (iron)' (SŠSM10, p. 92), (DSS, p. 276); ibrīk ‘water ewer, kettle’ (SŠSM10, p. 138), (IKS, p. 267); kaftan 'robe with long skirts and sleeves, caftan' (SŠSM10, p. 80), (DSS, p. 269), (ŞS, p. 338), (IKS, p. 105); kahve 'coffee' (SŠSM10, p. 112), (DSS, p. 267); kahve ibrīgil kahve ibrīk 'coffee pot' (SŠSM10, p. 102), (DSS, p. 274); kavanoz 'jar' (SŠSM10, p. 115), (IKS, p. 267); kazan 'large pot' (SŠSM10, p. 111), (IKS, p. 267); kebe 'felt jacket' (SŠSM10, p. 103), (IKS, p. 104), (DSS, p. 275); kemer 'belt' (SŠSM10, p. 87), (DSS, p. 276); kettān 'linen' (SŠSM10, p. 92), (DSS, p. 267); kilīm 'woven matting, kilim' (SŠSM10, p. 80), (DSS, p. 267), (ŞS, p. 335); kuşak 'belt' (SŠSM10, p. 66), (IKS, p. 104), (DSS, p. 267); kürek 'shovel' (SŠSM10, p. 135), (DSS, p. 311); kürk 'fur' (SŠSM10, p. 92), (IKS, p. 260), (DSS, p. 267); küpe 'earring' (SŠSM10, p. 132), (DSS, p. 269); legen 'bowl' (SŠSM10, p. 91), (DSS, p. 309); makrama, makreme 'large scarf; kerchief' (SŠSM10, p. 92), (IKS, p. 105), (DSS, p. 270); māşa 'tongs; pincers' (SŠSM10, p. 40), (DSS, p. 311); meşin 'leather; sheep leather' (SŠSM10, p. 36), (DSS, p. 275); ok ma 'a/ve yay 'arrow with bow' (SŠSM10, p. 36), (ŞS, p. 335); orak 'sickle' (SS̆SM10, p. 16), (IKS, p. 108); pabuç 'shoe; slipper' (SŠSM10, p. 119), (IKS, p. 104); pirinç 'rice' (SŠSM10, p. 119), (IKS, p. 109); peştamāl 'large bath towel' (SŠSM10, p. 92), (DSS, p. 267); șābūn 'soap' (SŠSM10, p. 92), (IKS, p. 109), (DSS, p. 267); șahan 'frying pan' (SŠSM10, p. 92), (IKS, p. 106), (DSS, p. 269), (ŞS, p. 340); șanduk/șandık 'chest, coffer' (SŠSM10, p. 92), (IKS, p. 267), (ŞS, p. 338); sepet 'bascet' (SŠSM10, p. 92), (DSS, p. 276); sīnī 'tray' (SŠSM10, p. 138), (IKS, p. 108); şāl 'shawl' (SŠSM10, p. 138), (DSS, p. 267); şem 'dān/şam 'dān 'candlestick' (SŠSM10, p. 92), (DSS, p. 356); tahta 'board' (SŠSM10, p. 8), (IKS, p. 264); țāṣ 'cup, bowl' (SŠSM10, p. 92), (IKS, p. 104), (DSS, p. 269), (ŞS, p. 340); tāva 'frying pan' (SŠSM10, p. 92), (IKS, p. 105); tencere 
'saucepan' (SŠSM10, p. 8), (DSS, p. 269), (ŞS, p. 335); tepsi 'tray' (SŠSM10, p. 92), (IKS, p. 258), (DSS, p. 269), (ŞS, p. 335); torba 'bag' (SŠSM10, p. 41), (IKS, p. 260); tülbend/dülbend 'muslin; gauze' (SSSSM10, p. 92), (IKS, p. 105); yașdlk 'pillow' (SŠSM10, p. 40), (IKS, p. 106), (DSS, p. 267); yorgan 'quilt' (SŠSM10, p. 92), (DSS, p. 270), (ŞS, p. 338); zarf 'cover; envelope' (SŠSM10, p. 133), (DSS, p. 267).

The above Turkish words were also used in the Crimea. Most of them can be found in any of the analysed volumes. The same objects and goods in different books can be indicative of a similar social status, the use of the same objects and tools. They are also an accurate reflection of the daily life of the inhabitants of the areas where the mentioned records were made. They constitute merely an extract of all the names which can be found. On the basis of the analysis of bequeathed items, some tendencies can be noticed: in the book from the Crimea, there are many names of animals, mainly livestock, and also fabrics, garments, and objects of daily life. Names of weapons and warrior's equipment occur rarely. In the quoted books from the area of the Ottoman Empire, clothing, home equipment and tools can mainly be found. Names of animals occur but occasionally.

\section{Elements Characteristic of the Crimean Tatar Language and Other Kipchak Languages Present in the Records}

A number of similarities in the notes from the judicial books from Turkey and the Crimea have been discussed. These mainly refer to the used formulae, legal terminology and some of the names of objects found in the official records. However, it should be emphasised that there are certain elements in the 10th book which distinguish it from the other sicills. In some cases, it can be observed that the Turkish forms were replaced by those characteristic of the Kipchak languages. Zajączkowski and Reychman $(1955$, p. 105) write: "The language of the Crimean Tatar documents in the earlier periods has some dialectal features. That is due to the local and Central Asian languages, which had their influence on the clerical practice, official language and terminology of diplomacy. (...) Even in the later periods, this language of the Crimean Khanate tends to contain more Persian and Arabic words and does not keep its own features." (my translation, K. S.-R.). Kołodziejczyk (2013, p. 76) states: "Khwarezmian-Turkish, the prevalent language of the Crimean office, was influenced by the Ottoman Turkish language, yet a strong influence of the Kipchak languages can be noticed already in 17th-century documents" (my translation, K. S.-R.). In other cases it is clearly evident that some words present in the Crimean book were unknown in the Ottoman Empire. They are not found in any of the records. Therefore, if one reads individual notes, it can be wrongly assumed that they do not occur at all or constitute only a minute percentage. An in-depth analysis makes it possible to find a big number of words (mainly names of cattle and horse coat colour), names and grammatical forms characteristic of the Kipchak languages which diversify the language of the judicial office in the Crimea. 
Doerfer (1959, p. 369) divides the dialects of the Crimea in the following manner: "the Crimean Ottoman was the Ottoman Turkish language already used on the southern coast; Central Crimean Turkish, which is divided into the north (Bakhchysarai), southern and eastern (Theodosia); Crimean Tatar used in the north-western and eastern part of the Crimean Peninsula". Some scholars, such as Samojlovič, recognise the division into Northern Turkish and Southern Turkish (Samojlovič 1916, pp. 4-5).

The 10th judicial book was most probably written in the office of the court of appeal of a kazasker in Bakhchysarai. The inhabitants of most of the regions of the Peninsula came to him, which is evidenced by the information about the origin of the plaintiffs and defendants who appeared before the court. This in turn surely resulted in the variety of the linguistic features in the court records. These elements will be presented on the basis of several examples which are especially worth paying attention to. They include the following:

i) Presence of the genitive suffix (genitivus) in the form - $n I \tilde{n}$ in the words ending with a consonant (-нИнъ) (Jankowski 1992, p. 273), instead of the Turkish -Iñ, e.g. Bek'niñ (SŠSM10, p. 52) 'Bek's'; Tayır 'niñ (SŠSM10, p. 18) 'Tayır's'.

ii) Presence of the accusative suffix (accusativus) in the Crimean Tatar form $-n I$ (-нИ) (Jankowski 1992, p. 273), instead of the Turkish -(y)I, e.g. ġuruşnı (SŠSM10, p. 73) 'kurush+Acc.'.

iii) Presence of the terminative suffix in the Crimean Tatar form of the southern dialect $+Q A s ̧ I$ (Jankowski 2010, p. 208), e.g. şubatııgaşına (SŠSM10, p. 1) 'till February'.

iv) Kipchak names of animals and objects which did not occur in the Turkish language at all or occurred but in a different form and/or the meaning has been identified in the Kazakh language and the Kazakh equivalents have been provided, e.g.:

Animals (especially horses and cattle): bayțal (SŠSM10, p. 113; SŠSM13, p. 32) 'filly' in Kaz.: байтал (KRS, p. 114); biye (SŠSM10, p. 113; SŠSM13, p. 37) 'mare' in Kaz.: бue (KRS, p. 149); cabag̀ (SŠSM10, p. 113) 'foal between sixth and twelfth month of life' in Kaz.: жабавы (KRS, p. 259); dönen (SŠSM10, p. 113; SŠSM13, p. 10) 'almost four years old foal, calf' in Kaz.: дөнен (KRS, p. 217); kunacın (SŠSM10, p. 113; SŠSM13, p. 16) 'three years old calf" in Kaz.: құнажын (KRS, p. 547); kunanca (SŠSM10, p. 112; SŠSM13, p. 10; SŠSM15, p. 38) 'camel or bull that is three years old' in Kaz.: құнанша (KRS, p. 547); kunan (SŠSM10, p. 113; SŠSM13, p. 37) 'almost three years old foal' in Kaz.: құнан (KRS, p. 547); serke (SŠSM10, p. 111) 'castrated goat' in Kaz.: серке (KRS, p. 715); urgaç (SŠSM10, p. 99) 'female animal' in Kaz.: ұрzambl (KRS, p. 899).

Various words: çoyun (SŠSM10, p. 119; SŠSM15, p. 57) 'cast iron' in Kaz.: шойbıн (KRS, p. 956); kayşı (SŠSM10, p. 36) 'scissors/shears' in Kaz.: қ̧aŭmbı (KRS, p. 446); kurd (SSSM10, p. 85) 'dried cheese' in Kaz.: құpm (KRS, p. 552); özen (SŠSM10, p. 79) 'river' in Kaz.: өзен (KRS, p. 652); pıçaḳ (SŠSM10, 
p. 40; SŠSM15, p. 25) 'knife' in Kaz.: пылшақ (KRS, p. 676); taba (SŠSM10, p. 7) 'frying pan' in Kaz.: maба (KRS, p. 676).

Selected names: Abay (SŠSM10, p. 127; OT, p. 1; Gafurov 1987, p. 116); Atay (SŠSM10, p. 137; Baski 1986, p. 10); Beriş (SŠSM10, p. 79; OT, p. 147); Bölek (SŠSM10, p. 79; OT, p. 166); Cāntay (SŠSM10, p. 79; OT, p. 217); Esenkeldi (SŠSM10, p. 125; OT, p. 266); Eşbolat (SŠSM10, p. 129; OT, p. 269); Koçkar (SŠSM10, p. 80; OT, p. 463); Kökey (SŠSM10, p. 137; Baski 1986, p. 71); Kökköz (SŠSM10, p. 137; Baski 1986, p. 71); Kudāy Berdi (SŠSM10, p. 118; OT, p. 483); Kutlu (SŠSM10, p. 137; OT, p. 508); Meñli (SŠSM10, p. 94; OT, p. 541); Tèmür (SŠSM10, p. 137; Gafurov 1987, p. 194); Tilemiş (SŠSM10, p. 11; OT, p. 746); Țoțay (SŚSM10, p. 131; OT, p. 804).

On the basis of the above names chosen from the 10th judicial book, some features of the Crimean Tatar language which distinguish it from the Ottoman Turkish language are clearly evident. They can be found in Çoban-zade (2009, pp. 76-77), and include: $v$ - (Ott.) verrdi (Hüdaverdi) $\sim b$ - (CTat.) berdi - Kudāy Berdi (SŠSM10, p. 118); g- (Ott.) Gökey, Gökgöz $\sim k^{-}{ }^{4}$ (CTat.) Kökey (SŠSM10, p. 137), Kökköz (SŠSM10, p. 137); d- (Ott.) Dilemiş $\sim t$ - (CTat.) Tilemiş (SŠSM10, p. 11)

\section{Names of Weights and Measures}

The majority of the units of measurement, mass and square measures used in the Crimea have their equivalents in the Ottoman Empire (with difference in weight, volume, etc.). There are also common units, such as arşın 'In Istanbul 1 arşın of the bazaar $($ çarşı $)=68 \mathrm{~cm} ; 1$ Crimean $\operatorname{arşın~(for~cotton~or~flax~goods)~}=1428$ arşın of Istanbul' (SOBS, pp. 175, 183), kile 'Istanbul standard 1 kile $=37$ cubic decimetres (Reg. of 1298/1881) (...), 1 Crimean kile (...) = 4 kilo of Istanbul' (SOBS, pp. 177, 183), okka '1 okka = 400 dirhems; 1 Crimean okka $=400$ dirhems $=3$ livre and 2 ounces of France' (SOBS, pp. 179, 183) and çuval '1 çuval (sack) = 2 kanțār (Aḳkermān Reg.); 1 çuval (of henna) = 150 okka' (SOBS, pp. 176, 183). In the Crimean judicial books, there are also some measurement units which were used only on the Crimean Peninsula or were not used in the Ottoman Empire. They are not present in Meninski's dictionary Thesaurus Linguarum Orientalium Turcicae-Arabicae-Persicae (Meninski 1680), and are also absent in Tarama (1995-1996), Derleme Sözlüğ̈̈ (1993) and the dictionaries by Zenker (1866/1994) and Clauson (1972). These include: bessere (used for the volume of crops) (SSSM10, p. 16) found in the work by Halil İnalcık (SOBS, p. 183). He defined this unit on the basis of Traité sur le commerce de la Mer Noire I by Claude Peyssonel (Peyssonel 1755-1787, p. 168) as the local equivalent of kile used in the Khanate: "There were various kiles or, as locally referred to, besseres in the lands under the Khan of the Crimea (...) Bahçesarāy: 1 Crimean bessere $($ of wheat $)=4$ kile of Istanbul $=80-90 \mathrm{okka}=112.816-115.380 \mathrm{~kg}$ ". In addi-

\footnotetext{
${ }^{4}$ Although $k$ and $g$ are rarely distinguished in notation.
} 
tion to bessere, we should also mention the unit of area $z \bar{a} n$ (SŠSM10, p. 49) which has been found in Radloff's dictionary Versuch eines Wörterbuches der Turkdialecte (Radloff 1911, p. 867) and is 800 fathoms long and 12.5 fathoms wide.

\section{Conclusion}

The analysis of functional vocabulary and legal terminology of the judicial books from various regions of the Ottoman Empire and the Crimea has shown that the records possess many common features. They include legal terms, formulae used by the clerks in their notes, names of objects and food products, units of measurement and mass (though they vary in their value). They also have a common language. All of the books were written in the Ottoman Turkish language. However, it must be noted that the language of the Crimean documents is simpler than that of the books written in Istanbul. It is also true for other books written outside the capital of the Ottoman Empire. It is most definitely connected with the types of documents and information found in the registries and court records. The grammatical forms characteristic of the Crimean Tatar language, Kipchak names, names of animals, units of measurement and mass, and names of objects distinguish the Crimean books from the other ones.

\section{Abbreviations and Editorial Symbols}

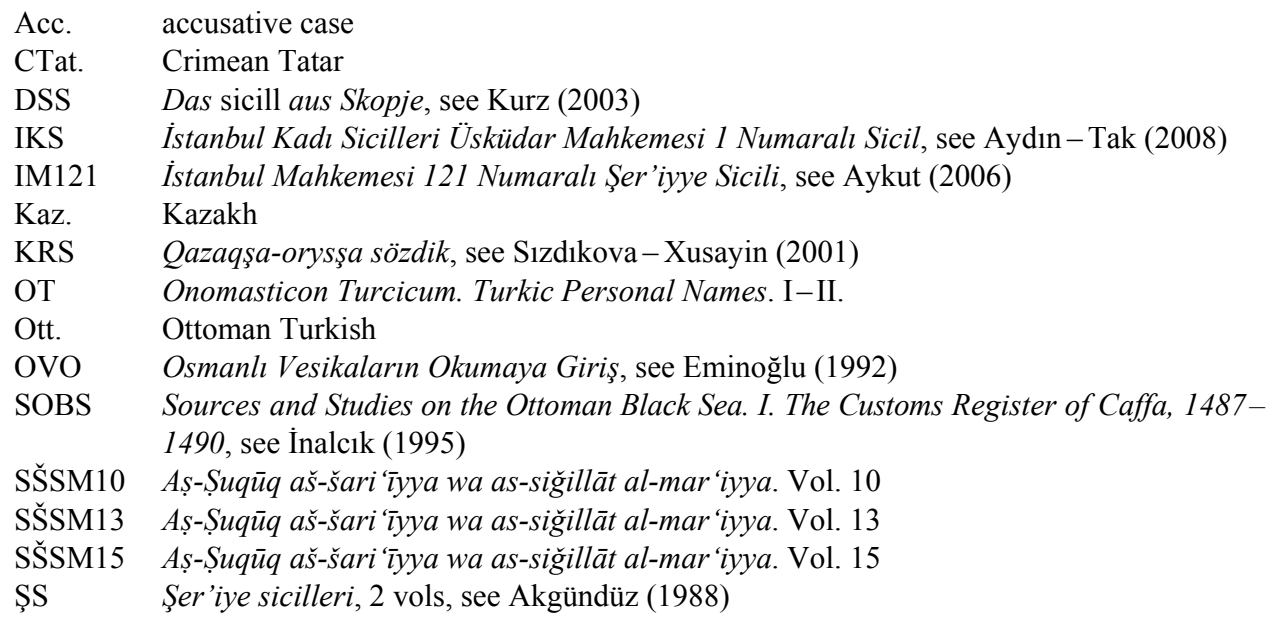

\section{References}

Akgündüz, A. (1988): Şer'iye sicilleri. 2 vols. İstanbul, Türk Dünyası Araştırmaları Vakfı. Aṣ-Ṣuqūq aš-šari '̌̀yya wa as-siǧillāt al-mar 'iyya. Vols 10, 13, 15. MS. Gasprinskis Library, Simferopol-St.Petersburg. 
Aydın, B.-Tak, E. (2008): İstanbul Kadı Sicilleri Üsküdar Mahkemesi 1 Numaralı Sicil. İstanbul, İsam Yayınları.

Aykut, Ş. N. (2006): İstanbul Mahkemesi 121 Numaralı Şer'iyye Sicili. İstanbul, Sabanc1 Üniversitesi.

Baski, I. (1986): A Preliminary Index to Rásonyi’s Onomasticon Turcicum. Budapest, Akadémiai Kiadó.

Clauson, G. (1972): An Etymological Dictionary of Pre-thirteenth-century Turkish. Oxford, Clarendon Press.

Çoban-zade, B. (2009): Kırım Tatar İlm-i Sarfi. Nariman Seyityahya (publisher). Ankara, Türk Dil Kurumu Yayınları.

[Derleme Sözlüğü] (1993): Derleme Sözlüğ̈̈ I-XI. Ankara, Ankara Üniversitesi Basımevi.

Devellioğlu, F. (2006): Osmanlıca-Türkçe Ansiklopedik Lugât. Ankara, Aydın Kitabevi Yayınları.

Doerfer, G. (1959): Das Krimtatarische. In: Deny, J.-Grønbech, K.-Scheel, H.-Togan, Z. V. (eds): Philologiae Turcicae Fundamenta. Vol. 1. Wiesbaden, F. Steiner, pp. 369-390.

Eminoğlu, M. (1992): Osmanlı Vesikaların Okumaya Giriş. Ankara, Türkiye Diyanet Vakfi.

Ergene, B. (2003): Local Court, Provincial Society and Justice in the Ottoman Empire: Legal Practice and Dispute Resolution in Çankırı and Kastamonu (1652-1744). Leiden, Brill.

Fekete, L. (1926): Einführung in die osmanisch-türkische Diplomatik der türkischen Botmässigkeit in Ungarn. Budapest, Königliche Ungarische Universitärsdruckerei.

Frantz, N. P. (1998): Material Culture, Understanding, and Meaning: Writing and Picturing. Journal of the American Academy of Religion Vol. 66, No. 4, pp. 791-815.

Gafurov, A. (1987): Imja i istorija. Ob imenah arabov, persov, tadzhikov i tjurkov. Slovar'. Moskva, Nauka.

Grzegorzewski, J. (1912): Z sidżlatów rumelijskich epoki wyprawy wiedeńskiej, akta tureckie [From Rumelian Sicills of the Vienna battle period, Turkish acts]. Lwów, Towarzystwo Popierania Nauki Polskiej.

İnalcık, H. (1995): Sources and Studies on the Ottoman Black Sea. I. The Customs Register of Caffa, 1487-1490. Cambridge, The Department of Near Eastern Languages and Civilisations.

Ivanics, M. (1975): Formal and Linguistic Peculiarities of 17th Century Crimean Tatar Letters Addressed to Princes of Transylvania. AOH Vol. 29, No. 2, pp. 213-224.

Jankowski, H. (1992): Gramatyka języka krymskotatarskiego [Crimean Tatar grammar]. Poznań, Wydawnictwo Naukowe Uniwersytetu im. Adama Mickiewicza.

Jankowski, H. (2010): Język krymskotatarski [Crimean Tatar language]. Warszawa, Wydawnictwo Akademickie Dialog.

Kołodziejczyk, D. (2013): Zaproszenie do osmanistyki [Invitation to Ottoman studies]. Warszawa, DiG.

Kurat, A. N. (1940): Topkapı arşivindeki Altın Ordu, Kırım ve Türkistan Hanlarına Ait Yarlık ve Bitikler. İstanbul, Bürhaneddin Matbaası.

Kurtoğlu, F. (1937): İlk Kırım hanlarının mektupları. Belleten Vol. 1, pp. 641-655.

Kurz, M. (2003): Das sicill aus Skopje. Kritische Edition und Kommentierung des einzigen vollständig erhaltenen Kadiamstsregisterbandes (sicill) aus Üsküb (Skopje). Wiesbaden, Harrassowitz Verlag.

Meninski, F. (1680): Thesaurus Linguarum Orientalium Turcicae-Arabicae-Persicae. Lexicon Turcico-Arabico-Persicum. Viennae Austriae.

Peyssonel, C. (1755-1787): Traité sur le commerce de la Mer Noire. 2 vols. Paris, Chez Cuchet.

Radloff, V. V. (1893-1911): Versuch eines Wörterbuches der Turkdialecte. 4 Bände. Sankt Petersburg. 
Rásonyi, L. - Baski, I. (2007): Onomasticon Turcicum. Turkic Personal Names. 2 vols. Bloomington, Indiana, Indiana University Denis Sinor Institute for Inner Asian Studies.

[Redhouse] (2000): Türkçe/Osmanlıca-İngilizce Sözlük. İstanbul, Sev Matbaacılık ve Yayıncılık.

Samojlovič, A. N. (1916): Opyt kratkoj krymsko-tatarskoj grammatiki. Petrograd, Tipografija I. Boroganskogo.

Sızdıkova, R. - Xusayin, K. (2001): Qazaqşa-oryş̧a sözdik. Almatı, Dajk-Press.

Stefaniak-Rak, K. (2011): Protokoły rozpraw sądowych XVII wiecznego Krymu. Analiza językowa i kulturowa [The proceedings of the hearings from 17th-century Crimea. A linguistic and cultural analysis]. Poznań, Uniwersytet imienia Adama Mickiewicza (unpublished doctoral dissertation).

Święcicka, E. (2002): The Diplomatic Letters by Crimean Kerey Ladies. Rocznik Orientalistyczny 55/1, pp. 57-91.

[Tarama] (1995-1996): Tarama Sözlüğ̈̈. 8 vols. Ankara, Ankara Üniversitesi Basımevi.

Vásáry, I. (1982): A Contract of the Crimean Khan Mängli Giräy and the Inhabitants of Qïrq-Yer from 1478/79. CAJ Vol. 26, pp. 289-300.

Véliaminov-Zernof, V. (1864): Matériaux pour servir à l'histoire du Khanat de Crimée. St-Pétersbourg.

Zajączkowski, A.-Reychman, J. (1955): Zarys dyplomatyki osmańsko-tureckiej [Handbook of Ottoman-Turkish Diplomatics]. Warszawa, Państwowe Wydawnictwo Naukowe.

Zenker, J. Th. (1866/1994): Türkisch-arabisch-persisches Handwörterbuch. Hildesheim, Georg Olms Verlag (1994 reprint of the 1866 Leipzig edition). 